\title{
Kinetic study on compositional variations of inclusions, steel and slag during refining process
}

\author{
Ying Zhang, Ying Ren, and Lifeng Zhang* \\ Beijing Key Laboratory of Green Recycling and Extraction of Metals (GREM), School of Metallurgical and Ecological \\ Engineering at University of Science, Technology Beijing (USTB), 100083 Beijing, PR China
}

Received: 23 April 2018 / Accepted: 8 June 2018

\begin{abstract}
A steel-slag-inclusion-alloy-refractory-air multiphase model, which combined the kinetic analysis and the consideration of fluid flow in argon-stirred ladle, was established to investigate the compositional changes during refining process. The steel-slag reaction, the steel and inclusion reaction, the refractory-steel reaction, the refractory dissolution into the slag, the reoxidation of the molten steel, the removal of inclusions by floating, and the alloy dissolution were all considered in the current model. The stirring energy, the average speed of the molten steel in the plume, the horizontal speed of the molten steel in the open eye, the speed of the molten steel near the side wall, the speed of the molten steel at the bottom of the ladle and the volume fraction of the plume were obtained by mathematical simulation. The mass transfer coefficient of the molten steel is obtained by mathematical simulation. Meanwhile, it is assumed that the mass transfer coefficient of inclusions is influenced by the temperature. The calculation results are in accordance with the experimental ones. The influence of different slag compositions, different gas flow rates, and different inclusion diameters on system compositions were also investigated using the current model. It is indicated that the content of T.O. in the molten steel was influenced by the gas flow rate and the removal rate of inclusions goes up with the increasing inclusion diameter.
\end{abstract}

Keywords: kinetic model / composition / inclusion / steel / refining process

\section{Introduction}

With the increasing demand for the high cleanliness of steel products, the accurate control of inclusion compositions become more and more important. Thermodynamic analysis is usually based on the assumption of equilibrium state among steel-slag-inclusion reactions. However, the real chemical reactions can hardly reach the equilibrium state during the practical process. In recent years, many researchers have established kinetic models to study the compositional changes during refining process [1-13]. The details of these models are listed in Table 1. It is indicated that the expressions of the stirring energy and the mass transfer coefficient are only suitable for certain conditions. Therefore, the calculations of the stirring energy and the mass transfer coefficient are obtained by mathematical simulation results in the current model.

Shin et al. [1] established a refractory-slag-metalinclusion multiphase reactions model to predict the evolution of inclusion during the secondary refining processes. Ying et al. [2] built a kinetic model to investigate

\footnotetext{
* e-mail: zhanglifeng@ustb.edu.cn
}

the evolution of inclusions after Ca treatment of Al-killed steel using Factsage macro processing. Ende et al. $[3,11]$ proposed an effective equilibrium reaction zone model using Factsage Macro Processing to simulate the compositional changes of steel and inclusions in ladle furnace as well as in the RH degassing process. Piva et al. [14] investigated the application of FactSage Macros Processing to simulate reaction kinetics of steel-slag and steel-inclusion in siliconmanganese killed steels. Bastida et al. [5] calculated composition changes during refining process using the coupled reaction model and obtained the relationship between the mass transfer coefficient and the stirring energy dissipation. Cicutti et al. [6] developed a kinetic model between steel and slag to investigate the influence of different parameters on the variations of inclusions. Kitamura et al. [7] built a steel-slag-inclusion-refractory model to investigate the variations of steel, slag and inclusions. Kang et al. [8] studied the $\mathrm{SiO}_{2}$ and $\mathrm{Al}_{2} \mathrm{O}_{3}$ content changes in mold flux using the double-film theory. Okuyama et al. [15] used the unreacted core model to calculate the change of $\mathrm{MgO}$ content in inclusions. Harada et al. $[9,10]$ developed a kinetic model to calculate compositional changes of steel, slag, and inclusions with the consideration of interactions among steel, slag, inclusion, alloy, and refractory. 
Table 1. Kinetic models to investigate the compositional changes during the refining process [1,3,5-11,15].

\begin{tabular}{|c|c|c|c|}
\hline Author & Research content & Parameter & Literature \\
\hline $\begin{array}{l}\text { Okuyama } \\
\text { et al. }\end{array}$ & $\begin{array}{l}\text { Calculated the } \mathrm{MgO} \\
\text { content change in inclusions } \\
\text { by the unreacted core model }\end{array}$ & $\begin{array}{l}\text { Diffusion coefficient of } \mathrm{Mg} \text { in inclusion: } 3.2 \times 10^{-13} \mathrm{~m}^{2} / \mathrm{s} \\
\text { Diffusion coefficient of Al in inclusion: } 3.5 \times 10^{-9} \mathrm{~m}^{2} / \mathrm{s}\end{array}$ & {$[15]$} \\
\hline $\begin{array}{l}\text { Shin-ya } \\
\text { et al }\end{array}$ & $\begin{array}{l}\text { Built a steel-slag-inclusion- } \\
\text { refractory model to } \\
\text { investigate the variations } \\
\text { of steel, slag and inclusions }\end{array}$ & $\begin{array}{l}\text { Mass transfer coefficient of the molten steel: } \\
k_{m}=(0.006 \pm 0.002) \dot{\varepsilon}^{(1.4 \pm 0.09)} \\
\text { Mass transfer coefficient of the slag: } k_{s}=k_{m} / 10 \\
\text { where } k_{m} \text { is the mass transfer coefficient of the molten steel, } \\
\mathrm{m} / \mathrm{s} ; k_{s} \text { is the mass transfer coefficient of the slag, } \mathrm{m} / \mathrm{s} ; \varepsilon \text { is the } \\
\text { stirring energy, W/t. }\end{array}$ & {$[16]$} \\
\hline $\begin{array}{l}\text { Harada } \\
\text { et al. }\end{array}$ & $\begin{array}{l}\text { Developed a kinetic model } \\
\text { including interactions } \\
\text { among steel, slag, } \\
\text { inclusion, alloy, and } \\
\text { refractory to calculate } \\
\text { compositional changes of } \\
\text { steel, slag and inclusions }\end{array}$ & $\begin{array}{l}\text { Mass transfer coefficient of the molten steel: } \\
k_{m}=(0.006 \pm 0.002) \dot{\varepsilon}^{(1.4 \pm 0.09)} \\
\text { Mass transfer coefficient of the slag: } k_{s}=k_{m} / 10 \\
\text { where } k_{m} \text { is the mass transfer coefficient of the molten steel, } \\
\mathrm{m} / \mathrm{s} ; k_{s} \text { is the mass transfer coefficient of the } \mathrm{slag}, \mathrm{m} / \mathrm{s} ; \varepsilon \text { is the } \\
\text { stirring energy, W/t. }\end{array}$ & {$[9,10]$} \\
\hline $\begin{array}{l}\text { Bastida } \\
\text { et al. }\end{array}$ & $\begin{array}{l}\text { Calculated composition } \\
\text { changes during the refining } \\
\text { process using coupled } \\
\text { reaction model and } \\
\text { obtained the relationship } \\
\text { between the mass transfer } \\
\text { coefficient and the stirring } \\
\text { energy dissipation }\end{array}$ & $\begin{array}{l}\text { Expression of the stirring energy: } \\
\varepsilon=371 \frac{Q T}{W}\left[\left(1-\frac{T_{0}}{T_{S}}\right)+\operatorname{In}\left(1+\frac{h_{L}}{1.48}\right)\right] \\
\text { Mass transfer coefficient of the molten steel: } \\
k_{m}=0.013 \varepsilon^{0.25} \text { for } \varepsilon<60 \mathrm{~W} / \mathrm{t} \\
k_{m}=8 \times 10^{-6} \varepsilon^{2.1} \text { for } \varepsilon>60 \mathrm{~W} / \mathrm{t} \\
\text { where } \varepsilon \text { is the stirring energy, } \mathrm{W} / \mathrm{t} ; Q \text { is the argon flow rate, } \\
\text { which is expressed at standard conditions, } \mathrm{m}^{3} / \mathrm{s} ; W \text { is the } \\
\text { weight of the molten steel, } \mathrm{t} ; h_{L} \text { is the ladle height, m; } T_{0} \text { is the } \\
\text { absolute temperature of the argon, } \mathrm{K} ; T_{S} \text { is the absolute } \\
\text { temperature of the molten steel, } \mathrm{K} ; k_{m} \text { is the mass transfer } \\
\text { coefficient of the molten steel, } \mathrm{m} / \mathrm{s} \text {. }\end{array}$ & {$[5]$} \\
\hline $\begin{array}{l}\text { Kang } \\
\text { et al. }\end{array}$ & $\begin{array}{l}\text { Studied the } \mathrm{SiO}_{2} \text { and } \mathrm{Al}_{2} \mathrm{O}_{3} \\
\text { content changes in mold } \\
\text { flux using double-film } \\
\text { theory }\end{array}$ & $\begin{array}{l}\text { Mass transfer coefficient of } \mathrm{Al} \text { in the film layer at } 1773 \mathrm{~K} \text { : } \\
0.9 \times 10^{-4} \mathrm{~m} / \mathrm{s} \text { to } 1.2 \times 10^{-4} \mathrm{~m} / \mathrm{s}\end{array}$ & {$[8]$} \\
\hline Shin et al. & $\begin{array}{l}\text { Established a refractory- } \\
\text { slag-metal-inclusion model } \\
\text { to predict the evolution of } \\
\text { inclusion during the } \\
\text { refining process }\end{array}$ & Mass transfer coefficient of $\mathrm{MgO}$ in slag: $5.0 \times 10^{-6} \mathrm{~m} / \mathrm{s}$ & {$[1]$} \\
\hline Ende et al. & $\begin{array}{l}\text { Proposed an effective } \\
\text { equilibrium reaction zone } \\
\text { model using Factsage macro } \\
\text { processing to simulate the } \\
\text { compositional changes of } \\
\text { steel and inclusions in ladle } \\
\text { furnace as well as in the RH } \\
\text { degassing process }\end{array}$ & $\begin{array}{l}\text { Expression of the stirring energy: } \varepsilon=\frac{n R T}{W} \operatorname{In}\left(\frac{P_{t}}{P_{0}}\right) \\
\text { Mass transfer coefficient of the molten steel: } k_{m}=0.006 \varepsilon^{1.4} \\
\text { where } k_{m} \text { is the mass transfer coefficient of the molten steel, } \\
\mathrm{m} / \mathrm{s} ; \varepsilon \text { is the stirring energy, } \mathrm{W} / \mathrm{t} ; R \text { is the ideal gas constant, } \\
\mathrm{J} /(\mathrm{mol} \cdot \mathrm{K}) ; W \text { is the weight of the molten steel, } \mathrm{t} ; n \text { is the molar } \\
\text { gas flow rate, mol } / \mathrm{s} ; T \text { is the temperature of the molten steel, } \mathrm{K} \text {; } \\
P_{t} \text { is the total gas pressure at the base of the ladle, } \mathrm{Pa} ; P_{0} \text { is the } \\
\text { gas pressure ar the surface of the molten steel, } \mathrm{Pa} \text {. }\end{array}$ & {$[3,11]$} \\
\hline
\end{tabular}


The kinetic model established by Harada is very comprehensive, which elaborates most of the interactions occurred during the ladle refining process, such as reactions between the molten steel and the slag, reactions between the molten steel and inclusions, the dissolution of the refractory into the slag, alloy dissolution and inclusion removal by floating. However, further investigations are still needed to improve the kinetic analysis during the LF refining. In the current study, a multiphase model which combines the kinetic calculation and the consideration of fluid flow in argon-stirred ladle was developed to calculate the composition changes of steel, slag and inclusions during ladle refining process. The mass transfer coefficient of the molten steel, the mass transfer coefficient of inclusions, possible reactions between steel-slag and steel-inclusion, reactions between the refractory and the molten steel, the reoxidation of the molten steel as well as the generation of sulfide inclusions were all improved based on mathematical simulation results compared to Harada's model. The calculation result was in accordance with the experimental result.

\section{Kinetic model}

The schematic diagram of the present model is shown in Figure 1. Reactions between the molten steel and the slag as well as that between the molten steel and inclusions, the dissolution of $\mathrm{MgO}$ refractory into both the molten steel and the slag, alloy dissolution into the metal, and the reoxidation of the molten steel caused by argon blowing are all considered in the present model. The flow chart of the calculation process is shown in Figure 2. It is assumed that the temperature of the molten steel can be maintained at $1873 \mathrm{~K}\left(1600^{\circ} \mathrm{C}\right)$. First, initial variables such as the initial composition of the molten steel, the initial composition of the slag, the initial composition of the inclusion, the gas flow rate, the weight of the molten steel and the slag were input in the model. Then the alloy addition was calculated, which alters the composition of the molten steel. Next, reactions between the molten steel and the slag, the dissolution of refractory, reactions between the molten steel and inclusions, the reoxidtion of the molten steel and the removal of inclusions by floating were carried out in turn. The compositional changes are calculated by a small time step $\Delta \mathrm{t}$, which is set as $0.1 \mathrm{~s}$. The calculation program was coded by Visual $\mathrm{C}++$.

\subsection{Reactions between the molten steel and the slag}

The reactions between the molten steel and the slag are calculated by the coupled reaction model, assuming chemical reactions at the interface are rapid and equilibrated at any time. The mass transfer process is considered as the rate-controlling step [10]. Possible reactions and their free energy changes of reactions are listed in Table 2 . The free energy changes of reactions could be calculated by equation (1). The reaction that has the most negative value of $\Delta \mathrm{G}$ is determined to occur. Calculations of the activity and the activity coefficients in the molten steel are given in equations (2) and (3) [4].

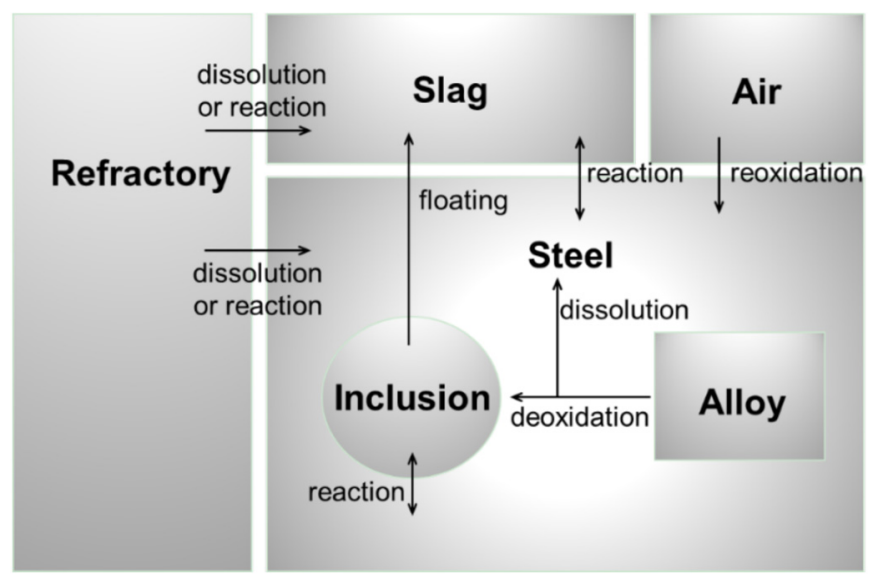

Fig. 1. Schematic diagram of multiphase reactions during refining process

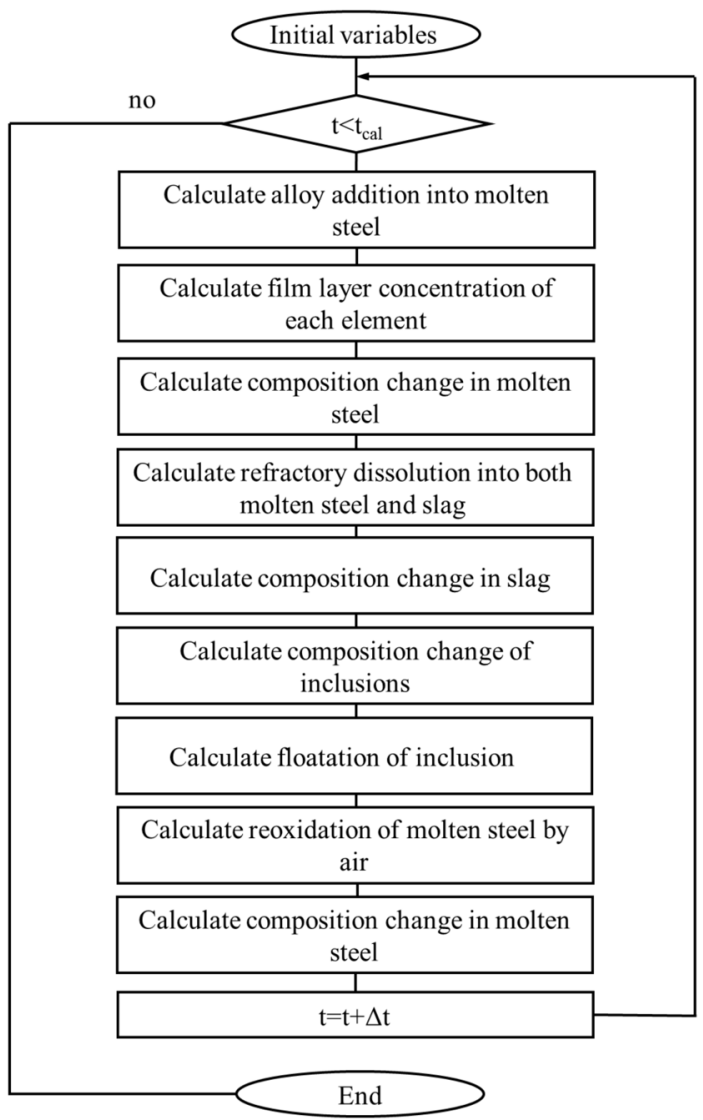

Fig. 2. Flow chart of the calculation process

And equation (4) is the equation to calculate the activity in the slag using the molecular structure theory of slag [17].

$$
\begin{gathered}
\Delta G=\Delta G^{\theta}+R T \operatorname{In} K, \\
a_{M}=f_{M} \cdot[\% M],
\end{gathered}
$$


Table 2. Considered reactions between the molten steel and the slag $[18,19]$.

\begin{tabular}{lll}
\hline Reaction 1 & $(\mathrm{CaO})=[\mathrm{Ca}]+[\mathrm{O}]$ & $\Delta G^{\theta}=138240.86+63.0 T$ \\
Reaction 2 & $3(\mathrm{CaO})+2[\mathrm{Al}]=\left(\mathrm{Al}_{2} \mathrm{O}_{3}\right)+3[\mathrm{Ca}]$ & $\Delta G^{\theta}=733560-59.7 T$ \\
Reaction 3 & $\left(\mathrm{Al}_{2} \mathrm{O}_{3}\right)=2[\mathrm{Al}]+3[\mathrm{O}]$ & $\Delta G^{\theta}=-1206220-390.39 T$ \\
Reaction 4 & $(\mathrm{CaO})+[\mathrm{S}]=(\mathrm{CaS})+[\mathrm{O}]$ & $\Delta G^{\theta}=102669-32.5 T$ \\
Reaction 5 & $3(\mathrm{MnO})+2[\mathrm{Al}]=3[\mathrm{Mn}]+\left(\mathrm{Al}_{2} \mathrm{O}_{3}\right)$ & $\Delta G^{\theta}=-376800+1.5 T$ \\
Reaction 6 & $3\left(\mathrm{SiO}_{2}\right)+4[\mathrm{Al}]=3[\mathrm{Si}]+2\left(\mathrm{Al}_{2} \mathrm{O}_{3}\right)$ & $\Delta G^{\theta}=-703190.01+121.8 T$ \\
Reaction 7 & $(\mathrm{MgO})=[\mathrm{Mg}]+[\mathrm{O}]$ & $\Delta G^{\theta}=89960+82.0 T$ \\
Reaction 8 & $3(\mathrm{MgO})+2[\mathrm{Al}]=3[\mathrm{Mg}]+\left(\mathrm{Al}_{2} \mathrm{O}_{3}\right)$ & $\Delta G^{\theta}=296752.4+21.7 T$ \\
Reaction 9 & $\left(\mathrm{SiO}_{2}\right)=[\mathrm{Si}]+2[\mathrm{O}]$ & $\Delta G=581900-221.8 T$ \\
Reaction 10 & $(\mathrm{MnO})=[\mathrm{Mn}]+[\mathrm{O}]$ & $\Delta G=288150-128.3 T$ \\
\hline
\end{tabular}

$$
\begin{gathered}
\log f_{M}=\sum_{j} e_{M}^{j}[\% j]+\sum_{j} \sum_{k} r_{M}^{j, k}[\% j][\% k]+\cdots, \\
a_{M O_{n}}=\frac{n_{M O_{n}}}{\sum n},
\end{gathered}
$$

where $R$ is the ideal gas constant, $\mathrm{J} /(\mathrm{mol} \cdot \mathrm{K}) ; K$ is the equilibrium constant; $[\% M, j$ or $k]$ represents the concentration of component $M, j$ or $k$ in the molten steel; $a_{M}$ is the activity of component $M$ in the molten steel; $a_{M O n}$ represents the activity of component $M O_{n}$ in slag; $f_{M}$ is the activity coefficient of component $M$ in the molten steel; $e_{M}^{j}$ and $r_{M}^{j}$ are the first and the second order interaction coefficients of $M$ on $j$ in the molten steel, respectively. $T$ is the absolute temperature, $\mathrm{K} ; n_{M O n}$ is the amount of substance of component $M O_{n}$ in the slag, mol; $\sum n$ is the total amount of substance in the slag. The values of first and second order interaction coefficients used in the present model were reported by published literatures $[4,18]$.

The flux density equations are calculated by equations (5-7). The total molar flux densities of cations and anions are assumed to be equal, as shown in equation (8). Then the concentration in the film layer can be calculated by solving above equations. Equations (9) and (10) are the equations to calculate the concentration changes of each component with time in the molten steel and slag, separately.

$$
\begin{gathered}
J_{M}=\frac{1000 k_{m} \cdot \rho_{\text {steel }}}{100 N_{M}}\left([\% M]^{b}-[\% M]^{*}\right), \\
J_{M O_{n}}=\frac{1000 k_{s} \cdot \rho_{\text {slag }}}{100 N_{M O_{n}}}\left(\left(\% M O_{n}\right)^{*}-\left(\% M O_{n}\right)^{b}\right), \\
J_{M}=J_{M O_{n}}, \\
\Sigma J_{M}=0, \\
\frac{d[\% M]}{\mathrm{d} t}=-\frac{A_{\text {steel-slag }} \cdot k_{m}}{V_{\text {steel }}}\left([\% M]^{b}-[\% M]^{*}\right),
\end{gathered}
$$

$$
\frac{d\left(\% M O_{n}\right)}{\mathrm{d} t}=-\frac{A_{\text {steel-slag }} \cdot k_{s}}{V_{\text {slag }}}\left[\left(\% M O_{n}\right)^{b}-\left(\% M O_{n}\right)^{*}\right],
$$

where $J_{M}$ is the molar flux density of element $M$ in the molten steel, $\mathrm{mol} /\left(\mathrm{m}^{2} \cdot \mathrm{s}\right) ; J_{M O n}$ is the molar flux density of $M O_{n}$ in the slag, $\mathrm{mol} /\left(\mathrm{m}^{2} \cdot \mathrm{s}\right) ; k_{m}$ represents the mass transfer coefficient in the molten steel, $\mathrm{m} / \mathrm{s} ; k_{s}$ represents the mass transfer coefficient in the slag, $\mathrm{m} / \mathrm{s} ; \rho$ is the density of the molten steel, $\mathrm{kg} / \mathrm{m}^{3}$; the subscript " $M$ " represents $\mathrm{Al}, \mathrm{Mg}, \mathrm{Ca}, \mathrm{Si}, \mathrm{Mn}, \mathrm{S}$ and $\mathrm{O} ; N_{M}$ represents the atomic weight of element $M, \mathrm{~g} / \mathrm{mol} ; N_{M O n}$ represents the atomic weight of element $M O_{n}, \mathrm{~g} / \mathrm{mol}$; the superscripts " $b$ " and "*" indicate bulk and interface concentrations, respectively; $V_{\text {steel }}$ is the volume of the molten steel, $\mathrm{m}^{3} ; V_{\text {slag }}$ is the volume of the slag, $\mathrm{m}^{3} ; A_{\text {steel-slag }}$ is the contact area between the molten steel and the slag, $\mathrm{m}^{2}$.

According to previous studies $[5,12,16,20]$, the mass transfer coefficient in the molten steel could be influenced by the stirring energy dissipation rate. The expression of the stirring energy dissipation rate obtained by mathematical simulation is given in equation (11). Figure 3 is the summarized relationship between the stirring energy and the mass transfer coefficient investigated by several researchers. Equation (12) shows the equation of the mass transfer coefficient of the molten steel used in the current model, which is obtained by calculating the average value of seven curves shown in Figure 3. According to previous studies, the ratio of $\mathrm{k}_{\mathrm{m}} / \mathrm{k}_{\mathrm{s}}$ is between 5 to 10 , which is independent on temperature, stirring condition and slag composition. Equation (13) is the equation of the mass transfer coefficient in the slag [10]. The cross section of the ladle is assumed to be trapezoid. All parameters used in the calculation of fluid flow in argon-stirred ladles are listed in Table 3.

$$
\begin{gathered}
\dot{\varepsilon}=0.30534 Q+0.000228, \\
k_{m}=0.0194 \dot{\varepsilon}^{0.688}, \\
k_{s}=k_{m} / 10,
\end{gathered}
$$




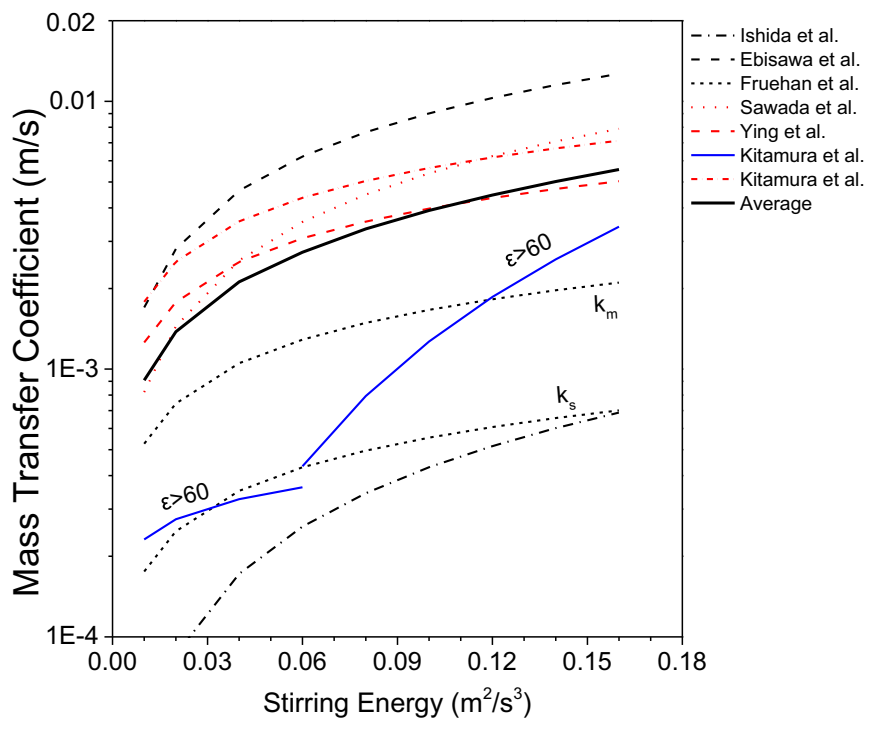

Fig. 3. The relationship between the stirring energy and the mass transfer coefficient $[5,10,32]$.

Table 3. Parameters used in mathematical simulation.

\begin{tabular}{lll}
\hline Ladle parameters & Capacity & $150 \mathrm{t}$ \\
& Height & $3.16 \mathrm{~m}$ \\
& Top diameter & $3.01 \mathrm{~m}$ \\
& Bottom diameter & $2.79 \mathrm{~m}$ \\
Plug parameters & Location & $\mathrm{r} / \mathrm{R}=0.538$ \\
& Separation angle & $135^{0}$ \\
& Dual plugs & \\
\hline
\end{tabular}

where $\dot{\varepsilon}$ is the stirring energy, $\mathrm{m}^{3} / \mathrm{s}^{2} ; Q$ represents the $\mathrm{Ar}$ flow rate at the bottom of the ladle, which is expressed at standard conditions, $\mathrm{m}^{3} / \mathrm{s} ; P_{1}$ represents the gas pressure under standard conditions, $\mathrm{Pa} ; k_{m}$ represents the mass transfer coefficient in the molten steel, $\mathrm{m} / \mathrm{s} ; k_{s}$ represents the mass transfer coefficient in the slag, $\mathrm{m} / \mathrm{s}$.

\subsection{Reactions between the molten steel and inclusions}

The calculation process of the molten steel and inclusions is similar to that of the molten steel and the slag. The contact area between the molten steel and the inclusion is considered as the superficial area of one single spherical inclusion with an average diameter of $2 \mu \mathrm{m}$, which is determined by Aspex results. Equation (14) is the equation to calculate the relative velocity between the inclusion particle and the molten steel [20]; equations (15) and (16) are equations to calculate the mass transfer coefficient of the molten steel and inclusion, separately. It is assumed that the mass transfer coefficient of the inclusion is influenced by the temperature. The solidus and the liquidus of the inclusion are calculated by polynomial regression using Factsage data. Equations (17) and (18) are equations to calculate the concentration changes of each component with time in the molten steel and the inclusion, separately.

$$
\begin{gathered}
u_{s l i p}=\frac{\left(\rho_{m} \rho_{i n c}\right) d_{p}^{2} g}{18 \mu_{m}} \\
k_{m \_i n c}=2\left(\frac{D_{M} u_{\text {slip }}}{\pi d_{p}}\right)^{1 / 2} \\
T>T_{L}, k_{i n c}=k_{m \_i n c} / 10 \\
\left.T<T_{L}, k_{i n c}=k_{m \_i n c} / 20\right\} \\
T<T_{S}, k_{i n c}=k_{m \_i n c} / 100 \\
\frac{d[\% M]}{\mathrm{d} t}=-\frac{n \cdot A_{s t e e l-i n c} \cdot k_{m \_i n c}}{V_{\text {steel }}}\left([\% M]^{b}-[\% M]^{*}\right) \\
\frac{d\left(\% M O_{n}\right)_{i n c}}{\mathrm{~d} t}=-\frac{6 \cdot k_{i n c}}{d_{p}}\left[\left(\% M O_{n}\right)_{i n c}^{*}-\left(\% M O_{n}\right)_{i n c}^{b}\right]
\end{gathered}
$$

where $u_{\text {slip }}$ is the relative velocity between the inclusion particle and the molten steel, $\mathrm{m} / \mathrm{s} ; k_{m}$ inc represents the mass transfer coefficient of the molten steel, $\mathrm{m} / \mathrm{s} ; k_{\text {inc }}$ represents the mass transfer coefficient of the inclusion particle, $\mathrm{m} / \mathrm{s} ; D_{M}$ is the diffusion coefficient of element M in the molten steel, $\mathrm{m}^{2} / \mathrm{s} ; d_{p}$ is the average diameter of the inclusion particle, $\mathrm{m} ; \mathrm{g}$ is the gravitational acceleration, $\mathrm{m} / \mathrm{s}^{2} ; \mu_{m}$ is the dynamic viscosity of the molten steel, $\mathrm{Pa} \cdot \mathrm{s} ; \rho_{\text {inc }}$ represents the density of inclusions, $\mathrm{kg} / \mathrm{m}^{3} ; \rho_{\text {steel }}$ represents the density of the molten steel, $\mathrm{kg} / \mathrm{m}^{3} ; T_{S}$ represents the solidus of the inclusion, $\mathrm{K} ; T_{L}$ represents the liquidus of the inclusion, $\mathrm{K} ; \mathrm{T}$ is the temperature of the inclusion, $\mathrm{K} ; n$ is the total number of inclusions; $A_{\text {steel-inc }}$ is the contact area between the molten steel and the inclusion, $\mathrm{m}^{2}$; the superscripts " $b$ " and "*" indicate bulk and interface concentrations, respectively. Considered reactions between the molten and inclusions and their free energy changes are listed in Table 4.

\subsection{Alloy dissolution into the molten steel}

The alloy dissolution could influence the composition of the inclusion and the slag indirectly by influencing the composition of the molten steel first. According to the previous study [21], the melting time of the added alloy can be calculated by equations (19-22). It is assumed that the velocity of the alloy particle is far less than the average speed of the molten steel. Therefore, the relative velocity between the molten steel and the alloy particle is approximately equal to the average speed of the molten steel.

$$
\begin{gathered}
t_{\text {alloy }}=\frac{C_{p, A} \rho_{A} d_{A}}{\pi h} \frac{T_{S}-T_{0}}{T_{M}-T_{S}}, \\
N u=\frac{d_{A} h}{\lambda_{m}}=2+\left(0.4 R e^{1 / 2}+0.06 \operatorname{Re}^{2 / 3}\right) \operatorname{Pr}^{0.4},
\end{gathered}
$$


Table 4. Considered reactions between the molten steel and inclusions [19].

\begin{tabular}{lll}
\hline Reaction 11 & $2[\mathrm{Al}]+3[\mathrm{O}]=\left(\mathrm{Al}_{2} \mathrm{O}_{3}\right)$ & $\Delta G^{\theta}=-296752.4-21.7 T$ \\
Reaction 12 & $3[\mathrm{Mg}]+\left(\mathrm{Al}_{2} \mathrm{O}_{3}\right)_{i n c}=3(\mathrm{MgO})_{i n c}+2[\mathrm{Al}]$ & $\Delta G^{\theta}=-1206220+390.39 T$ \\
Reaction 13 & $3[\mathrm{Ca}]+\left(\mathrm{Al}_{2} \mathrm{O}_{3}\right)_{i n c}=3(\mathrm{CaO})_{i n c}+2[\mathrm{Al}]$ & $\Delta G^{\theta}=-733500+59.7 T$ \\
Reaction 14 & {$[\mathrm{Ca}]+[\mathrm{S}]=(\mathrm{CaS})_{i n c}$} & $\Delta G^{\theta}=-530900+116.2 T$ \\
Reaction 15 & {$[\mathrm{Mg}]+[\mathrm{O}]=(\mathrm{MgO})_{i n c}$} & $\Delta G^{\theta}=-89960-82.0 T$ \\
Reaction 16 & {$[\mathrm{Ca}]+[\mathrm{O}]=(\mathrm{CaO})_{i n c}$} & $\Delta G^{\theta}=-138240.86-63.0 T$ \\
Reaction 17 & $3[\mathrm{Si}]+2\left(\mathrm{Al}_{2} \mathrm{O}_{3}\right)_{i n c}=3\left(\mathrm{SiO}_{2}\right)_{i n c}+4[\mathrm{Al}]$ & $\Delta G^{\theta}=703190.01-121.8 T$ \\
Reaction 18 & {$[\mathrm{Si}]+2[\mathrm{O}]=\left(\mathrm{SiO}_{2}\right)_{i n c}$} & $\Delta G=-581900+221.8 T$ \\
\hline
\end{tabular}

$$
\begin{gathered}
R e=\frac{\rho_{A} d_{A}\left|u_{m}-u_{A}\right|}{\mu}, \\
\operatorname{Pr}=\frac{C_{p, M} \mu_{m}}{\lambda_{m}}
\end{gathered}
$$

where $t_{\text {alloy }}$ is the melting time of the alloy, $\mathrm{s} ; C_{p, A}$ is the specific heat capacity of the alloy, $\mathrm{J} /(\mathrm{kg} \cdot \mathrm{K}) ; \rho_{A}$ is the density of the alloy, $\mathrm{kg} / \mathrm{m}^{3} ; d_{A}$ is the diameter of the alloy particle, $\mathrm{m} ; h$ represents the heat transfer coefficient on the surface of the alloy, which could be obtained by equation (22), $\mathrm{W} /\left(\mathrm{m}^{2} \cdot \mathrm{K}\right) ; T_{S}$ is the solidification temperature, $\mathrm{K}$; $T_{M}$ is the temperature of the molten steel, $\mathrm{K} ; T_{0}$ is the initial temperature of the alloy, $\mathrm{K} ; N u$ is the Nusselt number; $R e$ is the Reynolds number; $\operatorname{Pr}$ is the Prandtl number; $u_{A}$ is the velocity of the alloy particle, $\mathrm{m} / \mathrm{s} ; u_{m}$ is the average speed of the molten steel, $\mathrm{m} / \mathrm{s} ; \mu_{m}$ is the dynamic viscosity of the molten steel, $\mathrm{Pa} \cdot \mathrm{s} ; C_{p, M}$ is the specific heat capacity of the molten steel, $\mathrm{J} /(\mathrm{kg} \cdot \mathrm{K}) ; \lambda_{m}$ is the thermal conductivity of the molten steel, $\mathrm{J} /(\mathrm{m} \cdot \mathrm{s} \cdot \mathrm{K})$.

\subsection{Dissolution of $\mathrm{MgO}$ refractory into the slag}

The $\mathrm{MgO}$ based refractory is widely used in the steelmaking process due to its high melting point and excellent wear resistance. Many studies have showed that the dissolution of refractory can influence the $\mathrm{MgO}$ content in slag [22-26]. In this study, the refractory material is assumed to be $\mathrm{MgO}$. The dissolution of $\mathrm{MgO}$ refractory into the molten slag is taken into consideration. It is assumed that the mass transfer of $\mathrm{MgO}$ in the slag is the rate-controlling step [10], and the driving force of the refractory dissolution is the concentration difference of $\mathrm{MgO}$ between the slag and the film layer. The concentration of $\mathrm{MgO}$ in the film layer is assumed to be saturated [10]. The equation to calculate the concentration change of $\mathrm{MgO}$ with time in the molten slag is shown in equation (23). The calculation of the mass transfer coefficient of $\mathrm{MgO}$ is shown in equation (24) $[10,27]$. Equation $(25)$ is the equation to calculate the speed of the slag near the side wall. According to a previous study, it is indicated that the speed of the molten steel near the side wall is faster than that of the slag. Moreover, slag viscosity is much higher than steel viscosity. So, it is assumed that the speed of the slag near the side wall is one fifth of the speed of the molten steel. Equation (26) represents the expression of the speed of the molten steel near the side wall, which is obtained by mathematical simulation results.

$$
\begin{gathered}
\frac{d(\% M g O)}{\mathrm{d} t}=\frac{A_{\text {ref_slag }} k_{\text {ref_MgO }}}{V_{\text {slag }}}\left[(\% M g O)_{\text {ref }}^{*}-(\% M g O)^{b}\right], \\
k_{\text {ref_MgO }}=0.0791 R e^{-0.30} \cdot u_{\text {wall,slag }} / S c^{0.644}, \\
u_{\text {wall }, \text { slag }}=\frac{1}{5} u_{\text {wall,steel }}, \\
u_{\text {wall,steel }}=0.6624 Q^{0.3558},
\end{gathered}
$$

where $(\% \mathrm{MgO})_{\text {ref }}{ }^{*}$ represents the saturated concentration of $\mathrm{MgO}$ in the slag; $T$ is the temperature, $\mathrm{K} ; A_{\text {ref_slag }}$ is the contact area between the refractory and the slag phase, $\mathrm{m}^{2}$; $V_{\text {slag }}$ is the volume of the slag, $\mathrm{m}^{3} ; k_{\text {ref }} M g O$ is the mass transfer coefficient of $\mathrm{MgO}$ in the slag phase, $\mathrm{m} / \mathrm{s} ; R e$ represents the Reynolds number $\left(d \cdot u_{\text {wall,slag }} / v\right) ; S c$ is the Schmidt number $\left(v / D_{M g O}\right) ; d$ is the characteristic length, which is determined to be $1 / 2$ square of the contact area between the refractory and the slag, $\mathrm{m} ; u_{\text {wall.slag }}$ represents the speed of the slag near the side wall, $\mathrm{m} / \mathrm{s} ; u_{\text {wall.steel }}$ represents the speed of the steel near the side wall, $\mathrm{m} / \mathrm{s}$; $D_{M g O}$ is diffusion coefficient of $\mathrm{MgO}$ in the slag phase, $\mathrm{m}^{2} / \mathrm{s}$; $v$ is the kinetic viscosity, $\mathrm{m}^{2} / \mathrm{s} ; Q$ represents the gas flow rate, which is expressed at standard conditions, $\mathrm{m}^{3} / \mathrm{s}$.

\subsection{Dissolution of $\mathrm{MgO}$ refractory into the molten steel}

The refractory dissolution into the molten steel could influence compositions of the molten steel. Thus, the dissolution of $\mathrm{MgO}$ refractory into the molten steel is also taken into consideration. The calculation process was explained in the previous study [28]. Possible reactions taken into consideration are listed in Table 5. The equation to calculate the dissolution rate of $\mathrm{Mg}$ from the refractory is given in equation (27). It is assumed in the current model that the dissolution of $\mathrm{MgO}$ refractory into the molten steel near the side wall is Model I. And the dissolution of $\mathrm{MgO}$ refractory at the bottom of the ladle is Model II. The contact area between the molten steel and the refractory in 
Table 5. Considered reactions between the molten steel and the MgO refractory [19].

\begin{tabular}{lll}
\hline Reaction 19 & $M g O(s)=[M g]+[O]$ & $\Delta G^{\theta}=89960+82.0 T$ \\
Reaction 20 & $3 M g O(s)+2[A l]=A l_{2} O_{3}(s)+3[M g]$ & $\Delta G^{\theta}=296752.4+21.7 T$ \\
\hline
\end{tabular}

Model I is assumed to be a trapezoid, and the contact area between the molten steel and the refractory in Model II is assumed to be a circle. The summation of the contact area in Model I and Model II is the total contact area between the molten steel and the refractory. Equations $(28-30)$ and equation (26) are equations to calculate the mass transfer coefficient of $\mathrm{Mg}$ in Model I. Equations (28-29) and equations (31-32) are equations to calculate the mass transfer coefficient of $\mathrm{Mg}$ in Model II. Equation (34) is also obtained by mathematical simulation.

$$
\begin{gathered}
\frac{d[\% M g]}{\mathrm{d} t}=-\frac{A_{\text {steel_lining }} \cdot k_{\text {ref_Mg }}}{V_{\text {steel }}}\left([\% M g]^{b}-[\% M g]^{*}\right), \\
k_{\text {ref_Mg }}=1.3 R e^{1 / 2} S c^{1 / 3} D_{M g} / L \\
S c=\frac{v}{D_{M g}}, \\
R e=\frac{u_{\text {wall, steel }} \cdot L_{\text {wall, steel }}}{v} \\
R e=\frac{u_{\text {bottom, steel }} \cdot L_{\text {bottom, steel }}}{v} \\
u_{\text {bottom, steel }}=3.6359 Q^{0.8555}
\end{gathered}
$$

where $A_{\text {steel-lining }}$ is the contact area between the molten steel and the $\mathrm{MgO}$ refractory, $\mathrm{m}^{2} ; k_{\text {ref } \_ \text {Mg }}$ is the mass transfer coefficient of $\mathrm{Mg}$ in the molten steel, $\mathrm{m} / \mathrm{s} ;[\% \mathrm{Mg}]^{*}$ represents the equilibrium concentration of $\mathrm{Mg}$ in the film layer; $[\% \mathrm{Mg}]^{b}$ is the concentration of $\mathrm{Mg}$ in the molten steel; $Q$ represents the Ar gas flow rate, which is expressed at standard conditions, $\mathrm{m}^{3} / \mathrm{s} ; D_{M g}$ is the diffusion coefficient of $\mathrm{Mg}$ in the molten steel, $3.5 \times 10^{-9} \mathrm{~m}^{2} / \mathrm{s}$ [29]; Re is the Reynolds number; $S c$ is the Schmidt number; $u_{\text {wall,steel }}$ is the velocity of the molten steel near the side wall, $\mathrm{m} / \mathrm{s} ; u_{\text {bottom,steel }}$ is the velocity of the molten steel at the bottom of the ladle, $\mathrm{m} / \mathrm{s} ; v$ is the kinetic viscosity, $\mathrm{m}^{2 / \mathrm{s}}$; $L$ is the characteristic length, $\mathrm{m} ; L_{\text {wall,steel }}$ is the characteristic length in Model I, which is determined to be $1 / 2$ square of the contact area between the side wall of the ladle and the refractory, $\mathrm{m}$; $L_{\text {bottom,steel }}$ is the characteristic length in Model II, which is determined to be $1 / 2$ square of the contact area between the bottom of the ladle and the refractory, $\mathrm{m}$.

\subsection{Reoxidation of the molten steel by air}

In the present model, it is assumed that there is a direct contact area between the molten steel and the air due to the argon blowing. The molten steel could be reoxidized by air in this area. The calculation process of the reoxidation rate of the molten steel is shown in equations (33-39). According to previous study [30], the oxidation rate of the molten steel by air in the stirred state is controlled by the diffusion of $\mathrm{O}_{2}$ gas in the gas phase. Equation (34) [31] is the equation to calculate the mass transfer coefficient of oxygen. Equation (38) shows the relationship between the horizontal speed of the molten steel in the open eye. And equation (39) is the relationship between the plume area and the gas flow rate, which is expressed at standard conditions.

$$
\begin{gathered}
\frac{d[\% O]}{\mathrm{d} t}=\frac{M_{O} \cdot A_{\text {plume }} \cdot k_{O_{2}} \cdot\left(P_{O_{2}}-P_{O_{2}^{*}}\right)}{5 \cdot V_{\text {steel }} \cdot \rho_{\text {steel }} \cdot R \cdot T}, \\
k_{O_{2}}=0.664 R e^{1 / 2} \cdot S c^{1 / 3} \cdot D_{O_{2}} / L_{\text {eye }}, \\
R e=L_{\text {eye }} \cdot u_{\text {eye }} / v_{\text {gas }}, \\
S c=v_{\text {gas }} / D_{O_{2}}, \\
L_{\text {eye }}=\left(\frac{A_{\text {plume }}}{2 \pi}\right)^{1 / 2}, \\
u_{\text {eye }}=0.09+17.07 Q-432.53 Q^{2}, \\
A_{\text {plume }}=0.29+124.36 Q
\end{gathered}
$$

where $k_{O_{2}}$ represents the mass transfer coefficient of $\mathrm{O}_{2}, \mathrm{~m} / \mathrm{s}$; $P_{\mathrm{O} 2}$ is the partial pressure of $\mathrm{O}_{2}$ at the surface of the slag, $\mathrm{Pa} ; P_{\mathrm{O}^{*}}$ is the partial pressure of $\mathrm{O}_{2}$ at the interface between the molten steel and the slag, $\mathrm{Pa} Q Q$ is the gas flow rate, which is expressed at standard conditions, $\mathrm{m}^{3} / \mathrm{s} ; \rho_{\text {steel }}$ is the density of the molten steel, $\mathrm{kg} / \mathrm{m}^{3} ; D_{O 2}$ is the diffusion coefficient of $\mathrm{O}_{2}$ in the gaseous phase, which is estimated to be $1.75 \times 10^{-4} \mathrm{~m}^{2} / \mathrm{s}$ when the gas temperature is $800{ }^{\circ} \mathrm{C}$ [31]; $M_{O}$ represents the molecular weight of $\mathrm{O}$, $\mathrm{g} / \mathrm{mol} ; A_{\text {plume }}$ is the contact area between the molten steel and air in the plume region, $\mathrm{m}^{2} ; T$ is the temperature, $\mathrm{K} ; R$ represents the gas constant, $\mathrm{Pa} \cdot \mathrm{m}^{3} /(\mathrm{mol} \cdot \mathrm{K}) ; u_{\text {eye }}$ is the horizontal speed in the open eye, $\mathrm{m} / \mathrm{s} ; L_{\text {eye }}$ is radius of the plume area in the slag phase; $R e$ is the Reynolds number; $S c$ is the Schmidt number; $v_{\text {gas }}$ is the kinetic viscosity of gas phase, $\mathrm{m}^{2 /} \mathrm{s}$.

\subsection{Removal of inclusions by floating to the slag}

It is assumed that inclusions are uniformly distributed in the molten steel. The inclusion removal by floating could 
only happen in plume area, as shown in equation (41). The plume area is assumed to be a cone. The calculation for volume fraction of plume is shown in equation (40), which is obtained by mathematical simulation. Equation (42) is the expression of the average speed of the molten steel in the plume.

$$
\begin{gathered}
\alpha_{\text {plume }}=2.39+573.12 Q, \\
\frac{d n}{\mathrm{~d} t}=-\frac{2\left(u_{0}+u_{\text {slip }}\right)}{H} \cdot \frac{\alpha_{\text {plume }}}{100} \cdot n, \\
u_{0}=0.22+3.48 Q-158.08 Q^{2},
\end{gathered}
$$

where $n$ is the total number of inclusions; $H$ is the depth of the molten steel, $\mathrm{m} ; Q$ is the gas flow rate, which is expressed at standard conditions, $\mathrm{m}^{3} / \mathrm{s} ; \alpha_{\text {plume }}$ is the volume fraction of plume, $\% ; u_{0}$ represents the speed of the molten steel in the plume area, $\mathrm{m} / \mathrm{s} ; u_{\text {slip }}$ is the relative velocity between the molten steel and the inclusion, $\mathrm{m} / \mathrm{s}$.

\section{Validation of kinetic model}

\subsection{Investigations on inclusion evolution during LF refining}

Figure 4 is the schematic diagram of sampling during the ladle refining process of X65 pipeline steels. Compositional changes of the molten steel, the slag, and inclusions during the refining process were detected using automated SEM/ EDS inclusion analysis (ASPEX). Figures 5-9 are the composition distributions of inclusions during the LF refining. As it is shown, the inclusions mainly consist of $\mathrm{Al}_{2} \mathrm{O}_{3}$ at the LF start. The $\mathrm{Al}_{2} \mathrm{O}_{3}$ content in inclusions decreased with time while $\mathrm{MgO}, \mathrm{CaO}$, and $\mathrm{CaS}$ contents in inclusions are increasing. The inclusions are mainly $\mathrm{Al}_{2} \mathrm{O}_{3}-$ $\mathrm{MgO}-\mathrm{CaO}-\mathrm{CaS}$ complex inclusions. Figures 10-14 are mapping results of typical inclusions during the LF refining. The mapping results show that there are obvious increases in the $\mathrm{CaO}, \mathrm{CaS}$, and $\mathrm{MgO}$ contents, agreeing well with the composition evolution of inclusions in Figures 5-9. Figure 15 shows changes of the average diameter and the area fraction of inclusions during the LF refining. The area fraction of inclusions shows a decrease tendency, which is in accordance with the change of T.O. in the molten steel.

\subsection{Comparison of experimental and calculated results of the kinetic model}

Initial conditions for the calculation are listed in Table 6 . The refractory material is assumed to be the $\mathrm{MgO}$ refractory. Figures 16-18 are comparisons between calculated results and experimental results for compositional changes in the molten steel at $1873 \mathrm{~K}$. The increase of the dissolved $\mathrm{Al}$ in the molten steel is caused by the addition of alloy materials. The changes of T.Ca and T.S. in the metal are caused by reactions between the molten steel and the slag. The increase of T.Mg results from the refractory dissolution into the molten steel and reactions

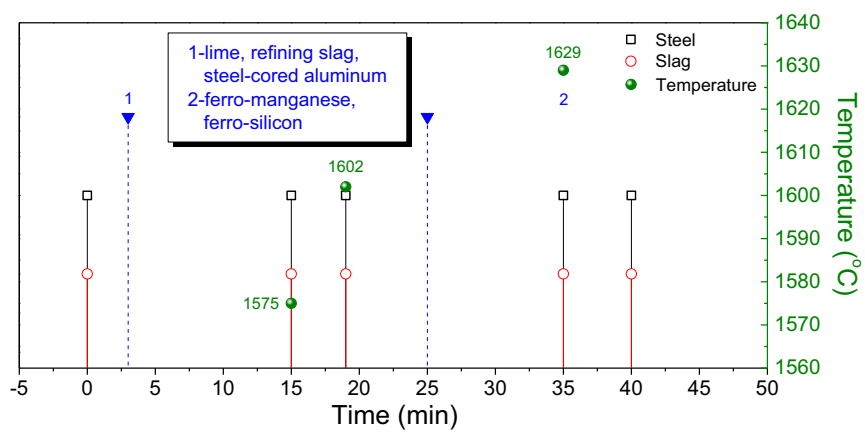

Fig. 4. Flow chart of sampling during refining process

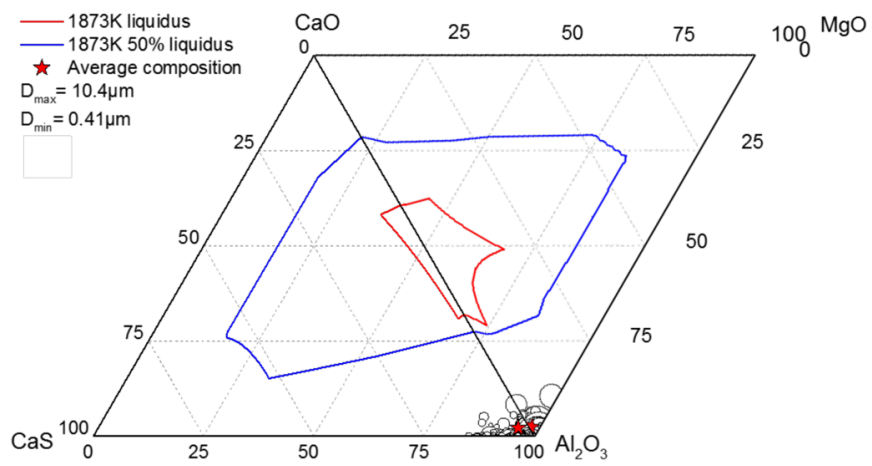

Fig. 5. Composition distribution of inclusions at the start of the LF refining.

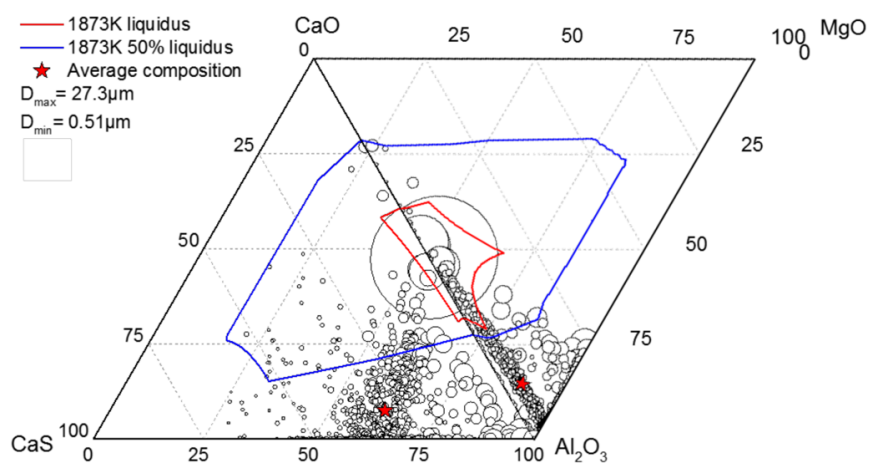

Fig. 6. Composition distribution of inclusions after the melting of the slag.

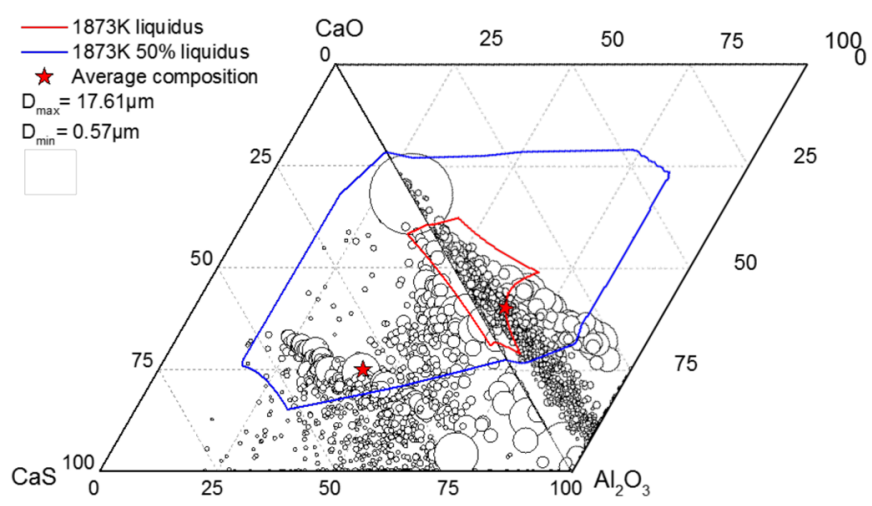

Fig. 7. Composition distribution of inclusions after the adjustment of the slag. 


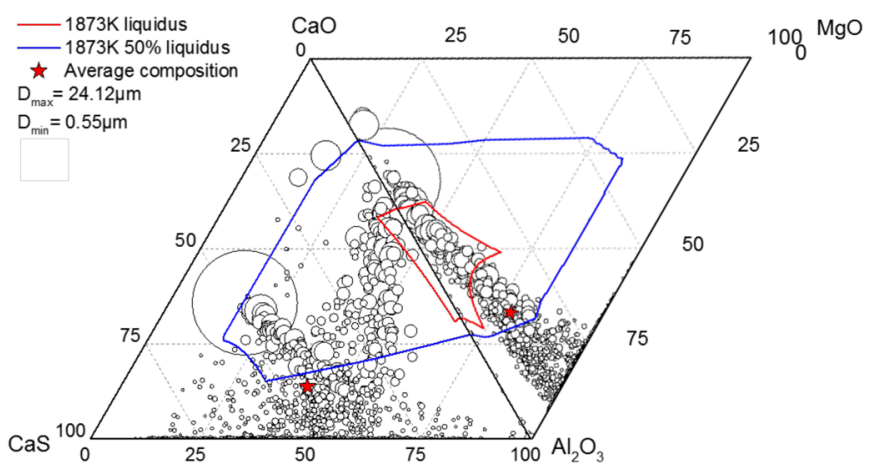

Fig. 8. Composition distribution of inclusions after the alloying.

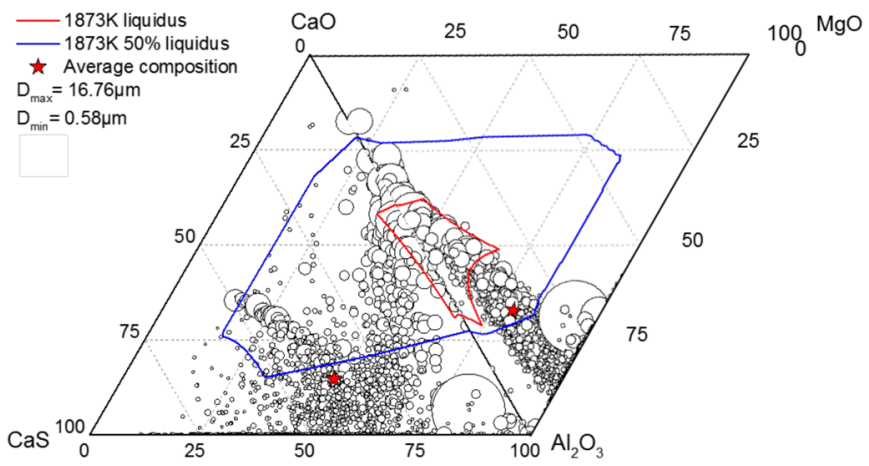

Fig. 9. Composition distribution of inclusions at the end of the LF refining.
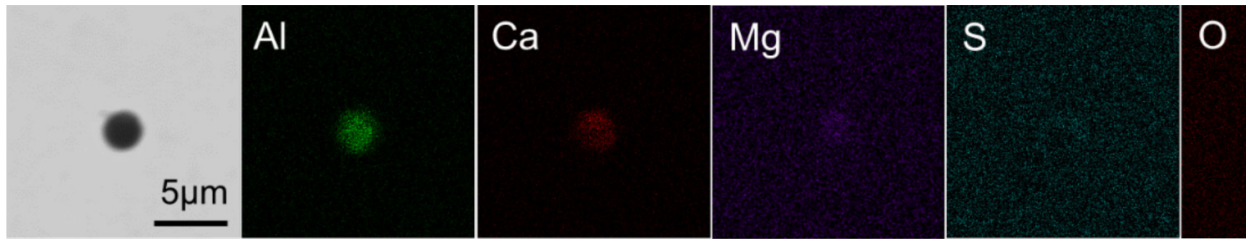

Fig. 10. Mapping of a typical inclusion at the start of the LF refining.
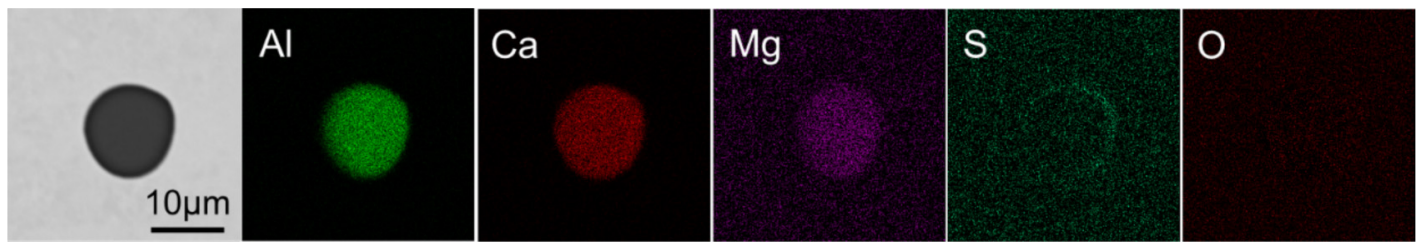

Fig. 11. Mapping of a typical inclusion after the melting of the slag.
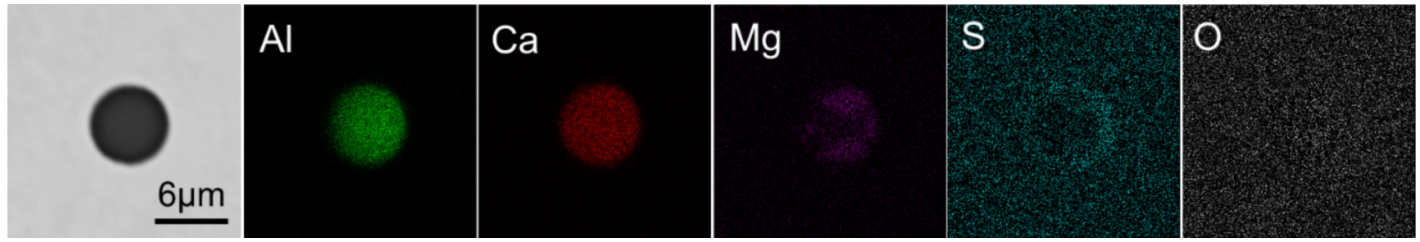

Fig. 12. Mapping of a typical inclusion after the adjustment of the slag.
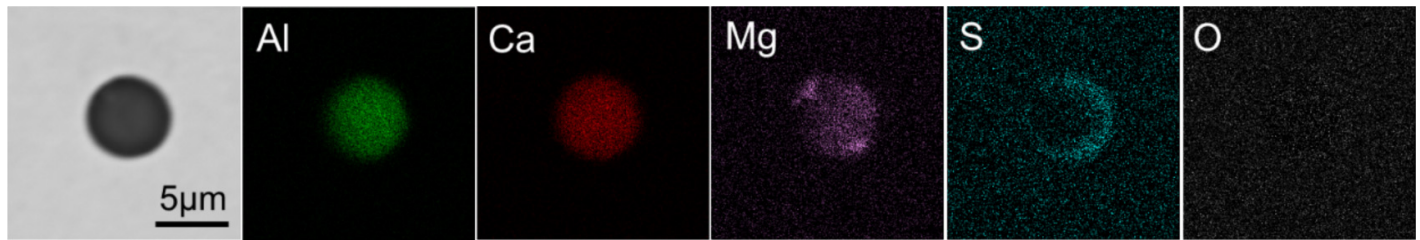

Fig. 13. Mapping of a typical inclusion after the alloying.

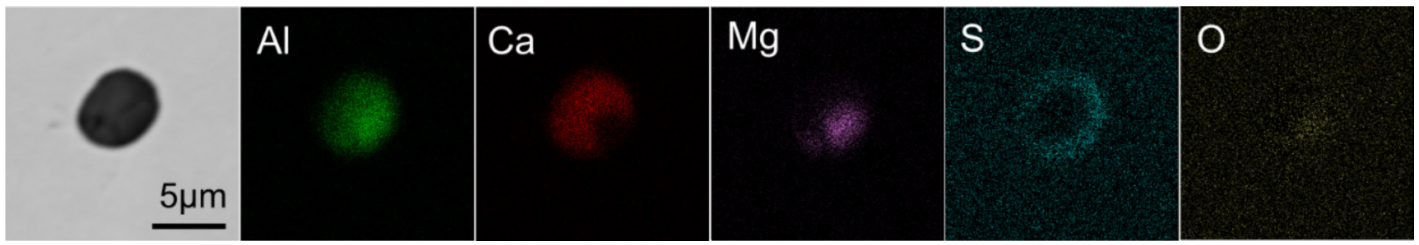

Fig. 14. Mapping of a typical inclusion at the end of the LF refining. 


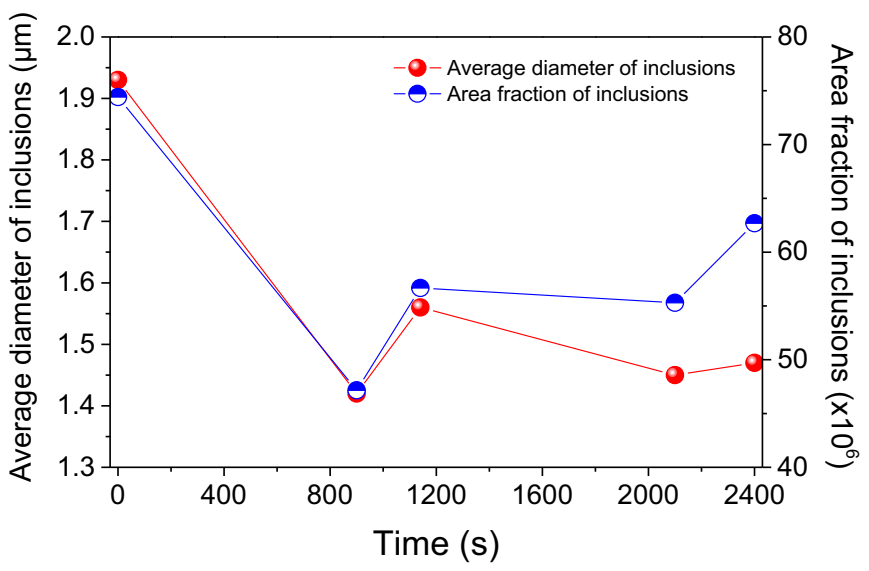

Fig. 15. Changes of the average diameter and the area fraction of inclusions during the LF refining.

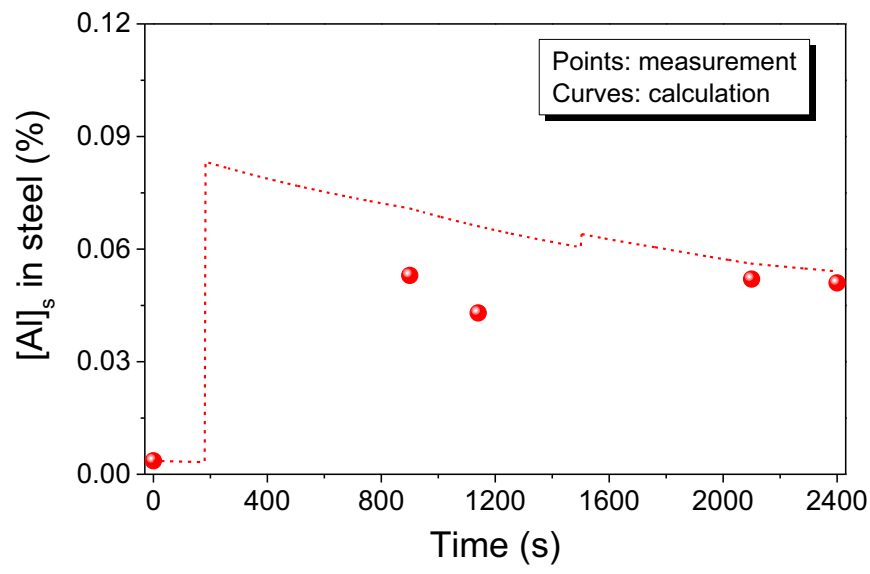

Fig. 16. Comparison between the calculated result and the experimental result of $\mathrm{Al}$ in the molten steel at $1873 \mathrm{~K}$.

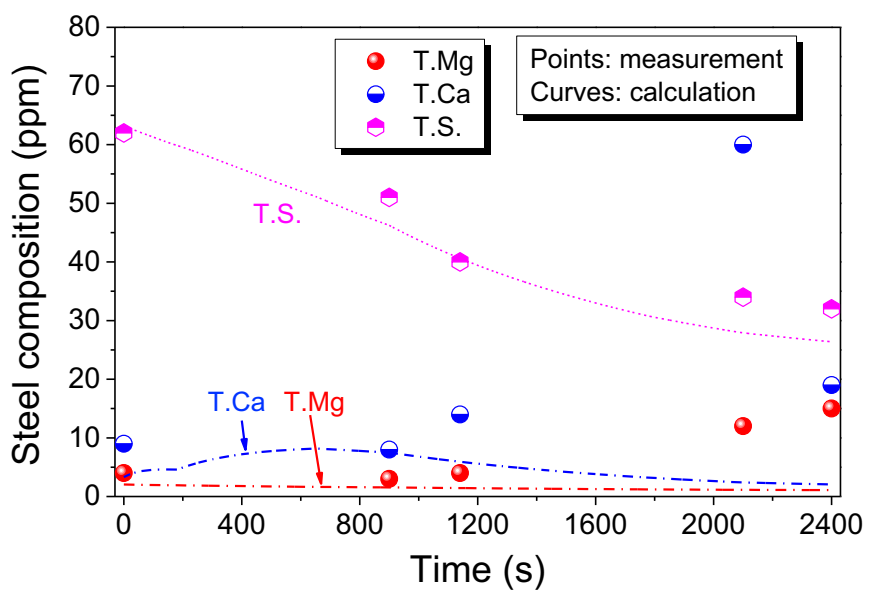

Fig. 17. Comparison between the calculated result and the experimental result of T.Ca, T.Mg and T.S. in the molten steel at $1873 \mathrm{~K}$.

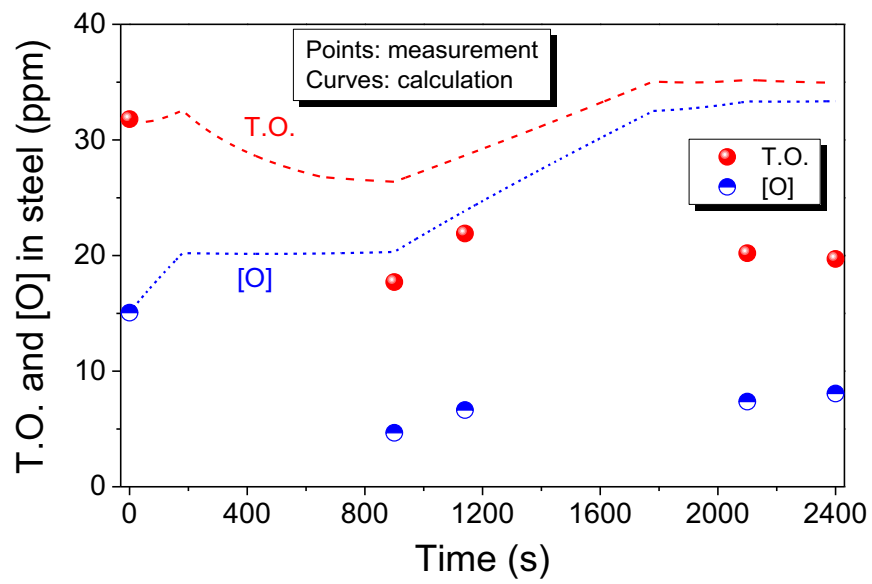

Fig. 18. Comparison between the calculated result and the experimental result of T.O. in the molten steel at $1873 \mathrm{~K}$.

Table 6. Initial conditions for the calculation.

\begin{tabular}{|c|c|c|c|c|c|c|}
\hline Steel composition & $\mathrm{C}$ & $\mathrm{Si}$ & Mn & $\mathrm{P}$ & {$[\mathrm{Al}]_{\mathrm{s}}$} & T.S. \\
\hline & 0.067 & 0.101 & 1.45 & 0.012 & 0.036 & 0.062 \\
\hline & $\mathrm{Ti}$ & $\mathrm{Cr}$ & $\mathrm{T} . \mathrm{Mg}$ & T.O. & T.Ca & \\
\hline & 0.0022 & 0.147 & 0.0004 & 0.0032 & 0.0009 & \\
\hline \multirow{2}{*}{$\begin{array}{l}\text { Slag composition } \\
(\%)\end{array}$} & $\mathrm{CaO}$ & $\mathrm{SiO}_{2}$ & $\mathrm{MnO}$ & $\mathrm{MgO}$ & $\mathrm{Al}_{2} \mathrm{O}_{3}$ & $\mathrm{Fe}_{2} \mathrm{O}_{3}$ \\
\hline & 47.49 & 8.79 & 11.70 & 5.07 & 21.49 & 3.11 \\
\hline \multirow{2}{*}{$\begin{array}{l}\text { Inclusion composition } \\
(\%)\end{array}$} & $\mathrm{Al}_{2} \mathrm{O}_{3}$ & $\mathrm{MgO}$ & $\mathrm{CaO}$ & $\mathrm{CaS}$ & & \\
\hline & 87.15 & 0.60 & 5.24 & 6.46 & & \\
\hline $\begin{array}{l}\text { Initial weight of steel } \\
\text { (t) }\end{array}$ & \multicolumn{6}{|c|}{150} \\
\hline $\begin{array}{l}\text { Initial weight of slag } \\
\text { (t) }\end{array}$ & \multicolumn{6}{|c|}{2.5} \\
\hline
\end{tabular}




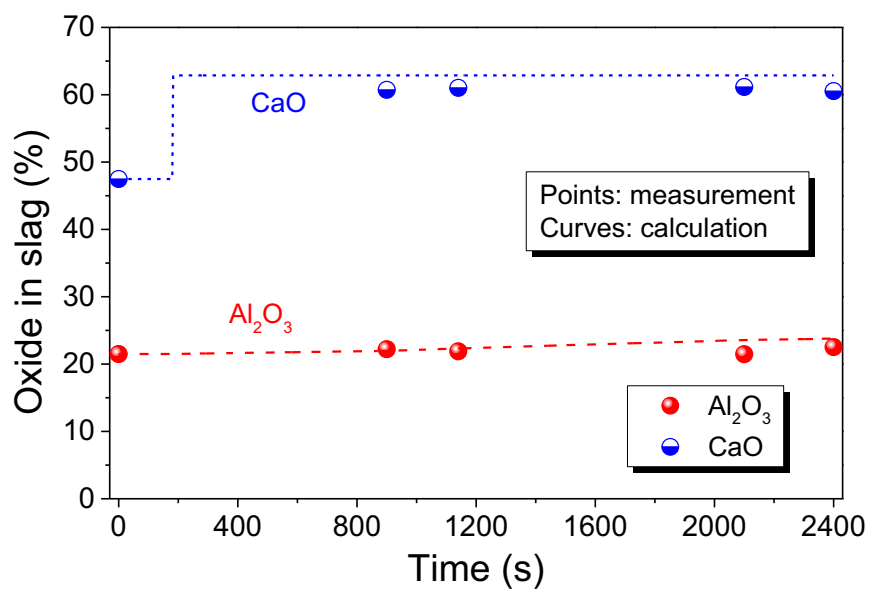

Fig. 19. Comparison between the calculated result and the experimental result of $\mathrm{CaO}$ and $\mathrm{Al}_{2} \mathrm{O}_{3}$ content in slag at $1873 \mathrm{~K}$.

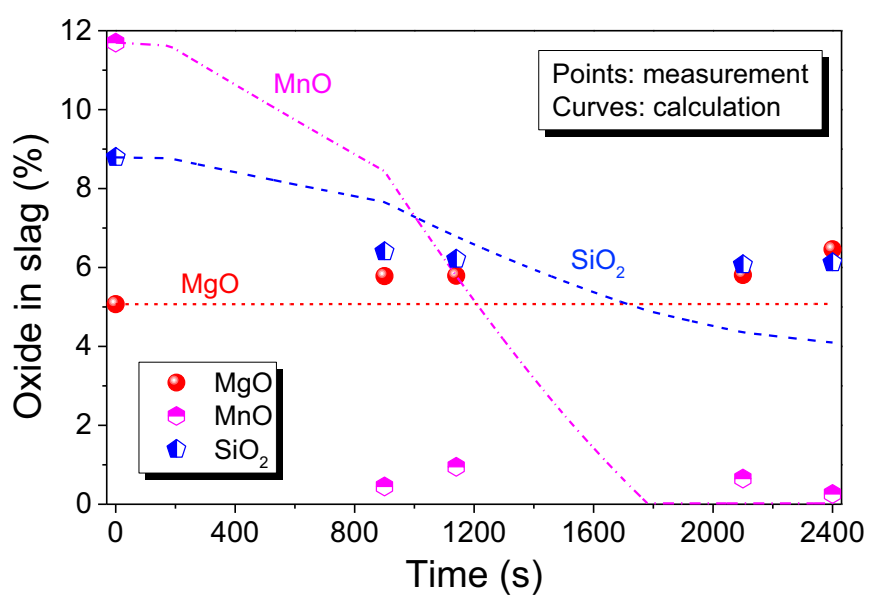

Fig. 20. Comparison between the calculated result and the experimental result of $\mathrm{SiO}_{2}, \mathrm{MnO}$ and $\mathrm{MgO}$ content in slag at $1873 \mathrm{~K}$.

between the molten steel and the slag. The change of T.O. in the molten steel is due to the reoxidation of the molten steel by the air, the inclusion removal by floating, and reactions between the molten steel and the slag. Figure 19 is the calculation result of T.O. and $[\mathrm{O}]$ in the molten steel without considering the reoxidation by the air. As it is shown in the figure, the predicted results become lower than actual results without considering the reoxidation process, indicating that there is reoxidation in the molten steel during the refining process. However, the calculation of reoxidation in the molten steel still needs further investigation in future studies.

Figures 19 and 20 are the comparison between calculated results and experimental results for oxides in slag at $1873 \mathrm{~K}$. The sharp increase of $\mathrm{CaO}$ in slag is due to the adjusting of the refining slag composition. The compositional changes of $\mathrm{Al}_{2} \mathrm{O}_{3}, \mathrm{SiO}_{2}$ and $\mathrm{MnO}$ are caused by reactions between the molten steel and the slag. The change of $\mathrm{MgO}$ content in slag is due to both the dissolution of refractory and reactions between the molten steel and

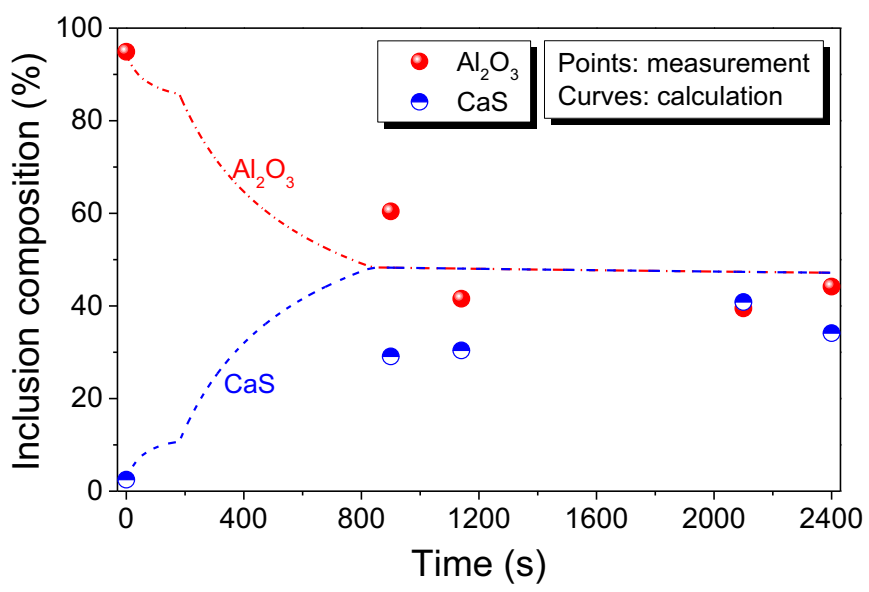

Fig. 21. Comparison between the calculated result and the experimental result of $\mathrm{CaS}$ and $\mathrm{Al}_{2} \mathrm{O}_{3}$ content in inclusion at $1873 \mathrm{~K}$.

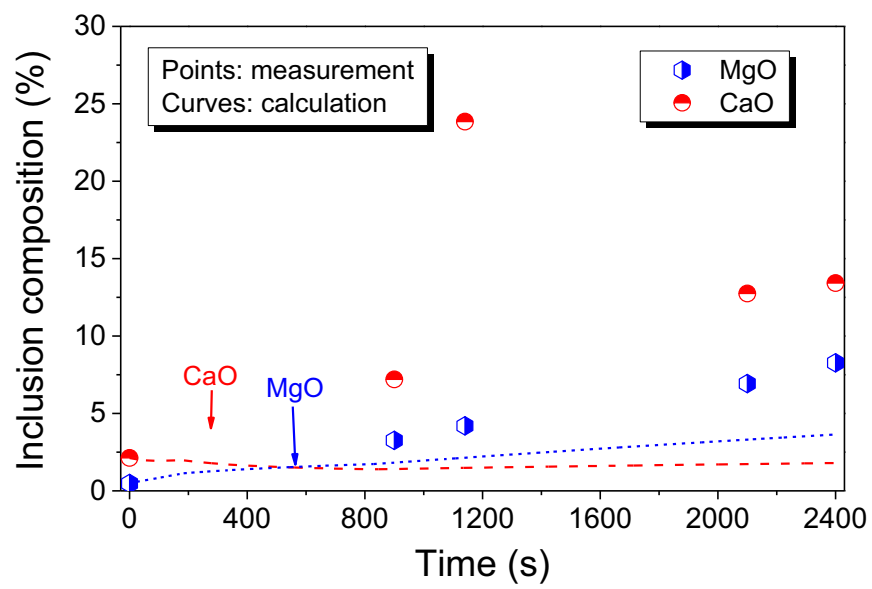

Fig. 22. Comparison between the calculated result and the experimental result of $\mathrm{CaO}$ and $\mathrm{MgO}$ content in inclusion at $1873 \mathrm{~K}$.

the slag. As it is shown, the calculation results of slag composition agrees well with the experimental ones, indicating the validity of the present model.

Figures 21-23 are comparisons between calculated results and experimental results of compositional changes in inclusion at $1873 \mathrm{~K}$. The $\mathrm{Al}_{2} \mathrm{O}_{3}$ content in inclusion decreases with the refining time, whereas the $\mathrm{MgO}, \mathrm{CaO}$ and $\mathrm{CaS}$ content of inclusion goes up. The changes of $\mathrm{Al}_{2} \mathrm{O}_{3}, \mathrm{CaS}, \mathrm{CaO}$ and $\mathrm{SiO}_{2}$ contents are influenced by reactions between the molten steel and inclusions. And the increase of $\mathrm{MgO}$ content is also due to both the dissolution of refractory and reactions between the molten steel and the slag. Calculation results of $\mathrm{Al}_{2} \mathrm{O}_{3}$ and $\mathrm{CaS}$ contents in inclusions are in good agreement with the experimental results. The difference between calculated and experimental results of $\mathrm{CaO}$ content and $\mathrm{MgO}$ content could be owing to the mass transfer coefficients of $\mathrm{CaO}$ and $\mathrm{MgO}$ in inclusions, which might need further improvement. Figure 24 is the calculation result of the inclusion amount, including oxide inclusions and sulfide inclusions. As it is 


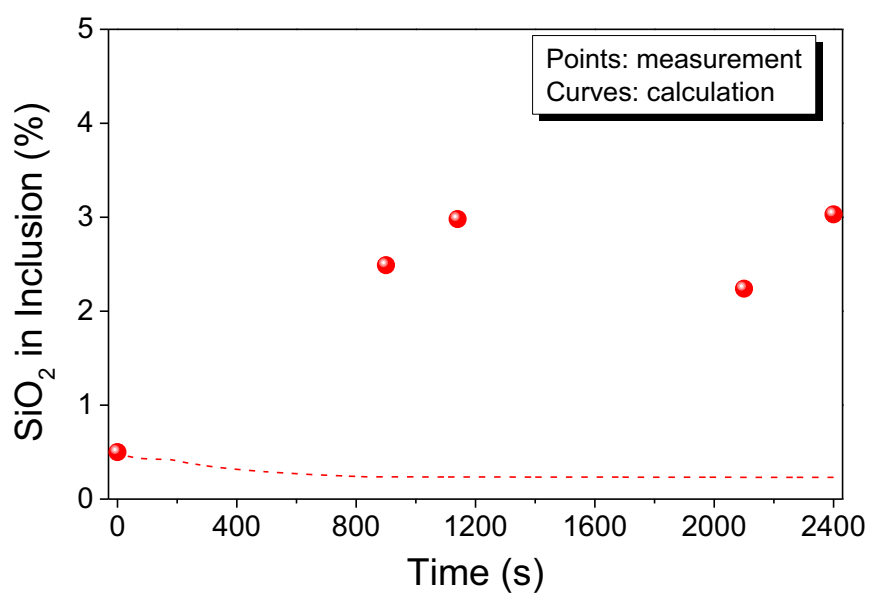

Fig. 23. Comparison between the calculated result and the experimental result of $\mathrm{SiO}_{2}$ content in inclusion at $1873 \mathrm{~K}$.

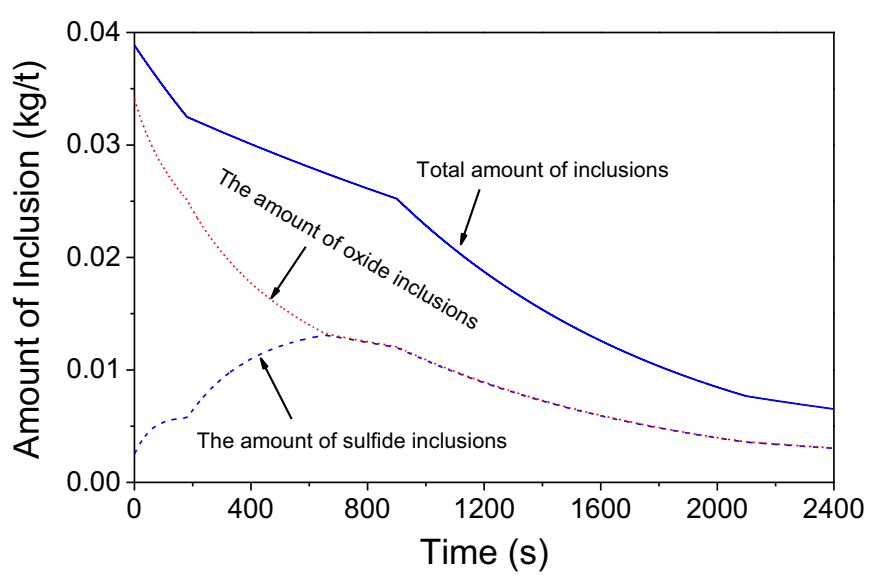

Fig. 24. Calculation of the amount of inclusions.

shown, the amount of sulfide inclusion first increased then decreased owing to the influence of $\mathrm{CaS}$ content in inclusions and the inclusion removal by floating.

\section{Application to predict compositional changes during refining process}

\subsection{The influence of slag basicity on inclusion composition}

In order to investigate the influence of different slag compositions, different gas flow rates, and different inclusion diameters on system compositions, the compositions of the molten steel and inclusions were calculated using the current kinetic model. The changed condition for the calculation is shown in Table 7 . Figures 25a-d are calculation results of $\mathrm{Al}_{2} \mathrm{O}_{3}, \mathrm{MgO}, \mathrm{CaO}$, and CaS contents in inclusion with different slag basicities, separately. As is shown in the figure, $\mathrm{Al}_{2} \mathrm{O}_{3}$ and $\mathrm{CaS}$ contents in inclusions rose up with the increasing slag basicity. The reason is that $\mathrm{SiO}_{2}$ content in the slag changes along with the basicity. And $[\mathrm{Al}]_{\mathrm{S}}$ in the molten steel increases when $\mathrm{SiO}_{2}$ content in the slag decreases, which leads to the increase of $\mathrm{Al}_{2} \mathrm{O}_{3}$
Table 7. Changed conditions for different slag basicities (\%).

\begin{tabular}{lrllll}
\hline $\mathrm{CaO}$ & $\mathrm{SiO}_{2}$ & $\mathrm{MnO}$ & $\mathrm{MgO}$ & $\mathrm{Al}_{2} \mathrm{O}_{3}$ & Basicity \\
\hline 61.33 & 10.22 & 0.45 & 5.78 & 22.21 & 6.0 \\
62.62 & 8.95 & 0.45 & 5.78 & 22.21 & 7.0 \\
63.61 & 7.95 & 0.45 & 5.78 & 22.21 & 8.0 \\
\hline
\end{tabular}

content in inclusions. $\mathrm{MgO}$ and $\mathrm{CaO}$ contents in inclusions reduced with the increasing slag basicity due to the increase of $\mathrm{Al}_{2} \mathrm{O}_{3}$ and $\mathrm{CaS}$ contents.

\subsection{Influences of different gas flow rates and inclusion diameters on T.O. in the molten steel}

Figure 26 is the influence of different gas flow rates on T.O. in the molten steel. As is shown, the content of T.O. in the molten steel increased with the increasing gas flow rate, indicating that a larger gas flow rate during the refining process would lead to a more serious reoxidation of the molten steel. The content change of T.O. in the molten steel when the gas flow rate goes up is owing to the increase of contact area between the molten steel and the air caused by argon blowing. The amount of inclusions decreased with the increase of inclusion diameter, as shown in Figure 27. It is indicated that the removal rate of inclusions goes up with the increasing inclusion diameter, which could influence the relative velocity between the molten steel and the inclusion. And the removal of inclusions by floating is then influenced by the relative velocity between the molten steel and the inclusion.

\section{Conclusions}

-a multiphase model combining the kinetic analysis and the consideration of fluid flow in argon-stirred ladle was developed to investigate the compositional changes during the refining process. The steel-slag reaction, the steelinclusions reaction, the dissolution of $\mathrm{MgO}$ refractory, the alloy dissolution, and the reoxidation of the molten steel caused by argon blowing were all considered;

-the stirring energy, the average speed of the molten steel in the plume, the horizontal speed of the molten steel in the open eye, the speed of the molten steel near the side wall, the speed of the molten steel at the bottom of the ladle and the volume fraction of the plume were obtained by the mathematical simulation. The mass transfer coefficients were calculated based on simulation results, and the calculation result was in accordance with the experimental result;

-influences of different slag compositions on inclusion compositions were investigated using the current model. The calculation results showed that $\mathrm{Al}_{2} \mathrm{O}_{3}$ and $\mathrm{CaS}$ contents in inclusions increased with the increasing slag basicity. However, $\mathrm{MgO}$ and $\mathrm{CaO}$ contents in inclusions decreased with the increasing slag basicity. Meanwhile, the calculation results also showed that the content of T.O. in the molten steel could be largely influenced by the gas flow 


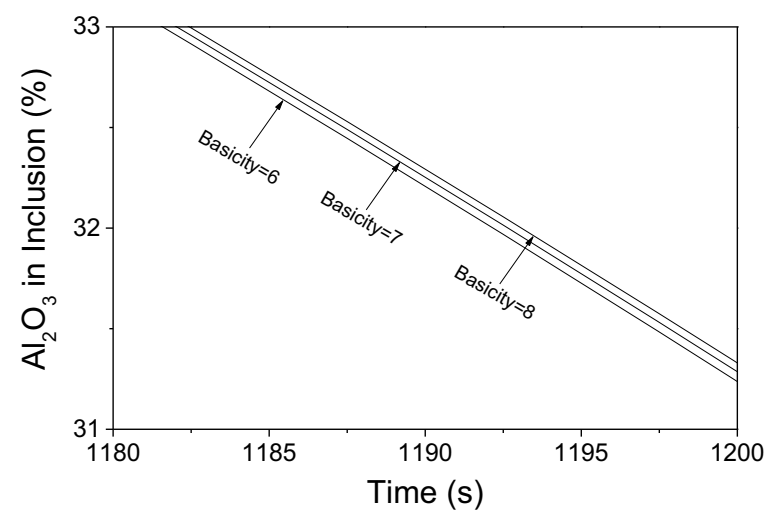

(a)

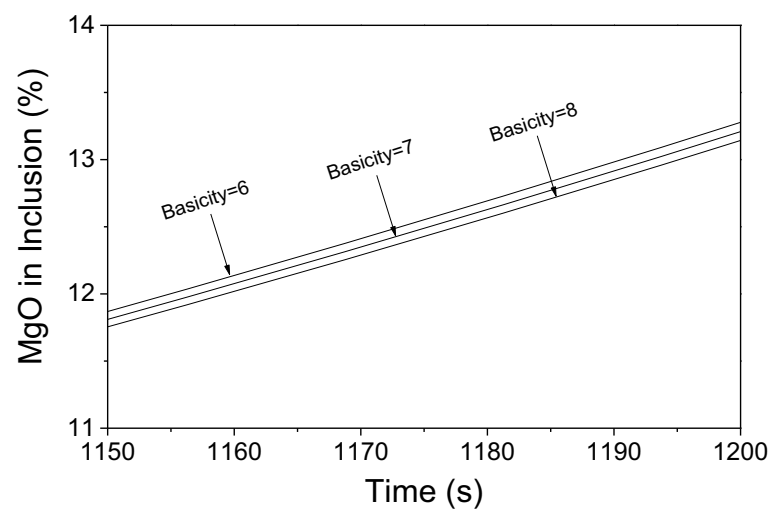

(b)

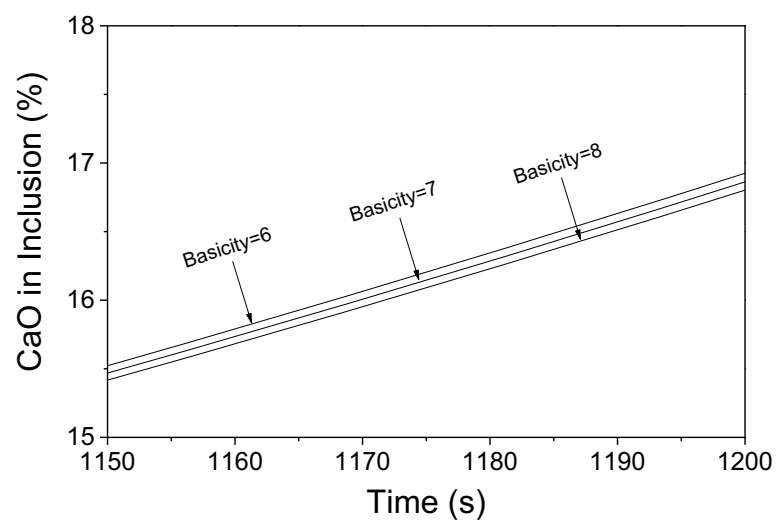

(c)

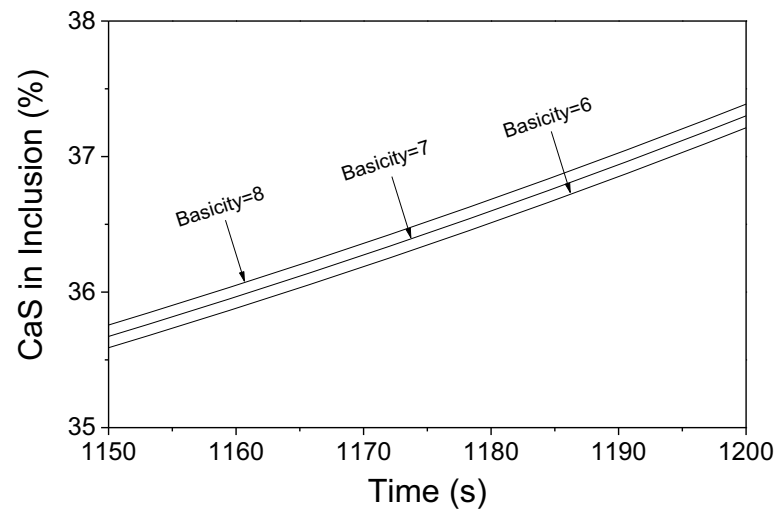

(d)

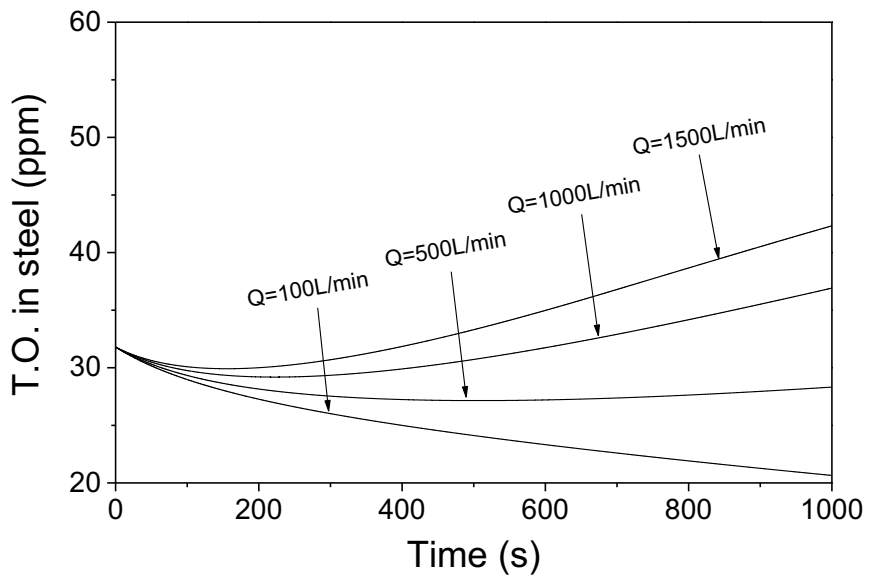

Fig. 26. Calculation of T.O. in the molten steel with different gas flow rates.

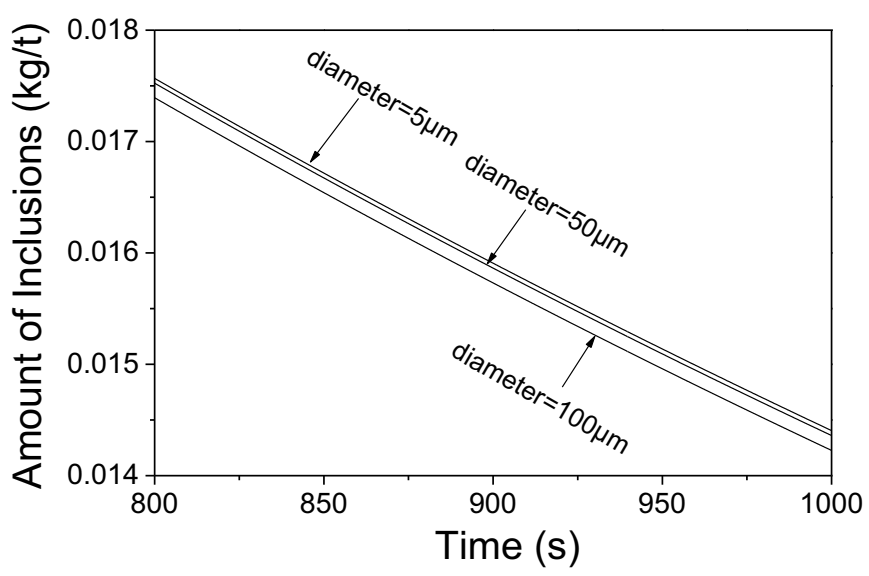

Fig. 27. Calculation of inclusion amounts in the molten steel with different inclusion diameters.

rate and the removal rate of inclusions goes up with the increasing inclusion diameter.

The authors are grateful for support from the National Key R\&D Program of China (2017YFB0304000\&2017YFB0304001), National Natural Science Foundation of China (Grant No. 51725402 and No. 51704018), Beijing Key Laboratory of Green Recycling and Extraction of Metals (GREM), the High Quality steel Consortium (HQSC) at the School of Metallurgical and Ecological Engineering at University of Science and Technology Beijing (USTB), China.

\section{References}

1. J.H. Shin, Y. Chung, J.H. Park, Metall. Mater. Trans. B 48, 1-14 (2017)

2. Y. Ren, Y. Zhang, L. Zhang, Ironmak. Steelmak. 44, 497-504 (2017)

3. M.-A.V. Ende, I.-H. Jung, Metall. Mater. Trans. B 48, 28-36 (2017)

4. L. Zhang, Y. Ren, H. Duan, W. Yang, L. Sun, Metall. Mater. Trans. B 46, 1809-1825 (2015)

Fig. 25. Calculation of compositional changes in inclusion with different slag basicities. 
5. A. Najera-Bastida, M.R. D, L. Garcia-Demedices, et al., ResearchGate 2015, (2015)

6. C. Cicutti, C. Capurro, G. Cerrutti, The 9th Int. Conf. on Clean Steel, 2015

7. S. Kitamura. TMS 2014 143th Annual Meeting \& Exhibition, 2014

8. Y.-B. Kang, M.-S. Kim, S.-W. Lee, et al., Metall. Mater. Trans. B 44, 309-316 (2013)

9. A. Harada, N. Maruoka, H. Shibata, S. Kitamura, Iron Steel Inst. Japan Int. 53, 2118-2125 (2013)

10. A. Harada, N. Maruoka, H. Shibata, S. Kitamura, Iron Steel Inst. Japan Int. 53, 2110-2117 (2013)

11. M.-A.V. Ende, Y.-M. Kim, M.-K. Cho, et al., Metall. Mater. Trans. B 42, 477-489 (2011)

12. A.N. Conejo, F.R. Lara, M. Macias-Hernandez, et al., Steel Res. Int. 78, 141-150 (2007)

13. J. Peter, K.D. Peaslee, D.G.C. Robertson, B.G. Thomas, AISTech 55 (2005)

14. S.P.T. Piva, D. Kumar, P.C. Pistorius, Metall. Mater. Trans. B 48, 37-45 (2017)

15. G. Okuyama, K. Yamaguchi, S. Takeuchi, K. Sorimachi, Iron Steel Inst. Japan Int. 40, 121-128 (2000)

16. S.-y. Kitamura, K.-i. Miyamoto, H. Shibata, et al., Iron Steel Inst. Japan Int. 49, 1333-1339 (2009)

17. J. Zhang, Physical chemistry of metallurgy [M], Metallurgical Industry Press, Beijing, 2004

18. H. Itoh, M. Hino, S. Ban-Ya, Metall. Mater. Trans. B 28, 953-956 (1997)
19. J.H. Park, H. Todoroki, Iron Steel Inst. Japan Int. 50, 1333-1346 (2010)

20. S.-y. Kitamura, T. Kitamura, K. Shibata, et al., Iron Steel Inst. Japan Int. 31, 1322-1328 (1991)

21. L. Zhang, F. Oeters, Steel Res. 70, 128-134 (1999)

22. J. Bygden, T. DebRoy, S. Seetharaman, Ironmak. Steelmak. 21, 318-323 (1994)

23. S. Jansson, V. Brabie, P. Jonsson, Scand. J. Metall. 34, 283-292 (2005)

24. S. Jansson, V. Brabie, P. Jonsson, Ironmak. Steelmak. 33, 389-397 (2006)

25. H. Matsuno, Y. Kikuchi, Tetsu-to-Hagane 88, 48-50 (2002)

26. P. Zhang, S. Seetharaman, J. Am. Ceram. Soc. 77, 970-976 (1994)

27. I. Sawada, T. Ohashi, Tetsu-to-Hagane 73, 669-676 (1987)

28. F. Hunag, L. Zhang, Y. Zhang, Y. Ren, Metall. Mater. Trans. B 48, 2195-2206 (2017)

29. J. Chen, Formula book of graphs and data during steelmaking process [M], Metallurgical Industry Press, Beijing, 2010

30. K. Sasai, Y. Mizukami, Iron Steel Inst. Japan Int. 36, 388-394 (1996)

31. K. Sasai, Y. Mizukami, Iron Steel Inst. Japan Int. 38, 332-338 (1998)

32. S.-Y. Kitamura, T. Kitamura, K. Shibata, Y. Mizukami, S. Mukawa, J. Nakagawa, Iron Steel Inst. Japan Int. 31, $1322-1328(1991)$

Cite this article as: Ying Zhang, Ying Ren, Lifeng Zhang, Kinetic study on compositional variations of inclusions, steel and slag during refining process, Metall. Res. Technol. 115, 415 (2018) 